-Slavica

Acta Baltico-Slavica, 45

Warszawa 2021
Citation: Krawczuk, A. (2021). „Gazeta Polska Bukowiny” jako źródło do badań współczesnej polszczyzny pisanej na Ukrainie. Acta Baltico-Slavica, 45, Article 2438. https://doi.org/10.11649/abs.2438

\author{
Atta Krawczuk \\ Narodowy Uniwersytet Lwowski im. Iwana Franki \\ Lwów \\ alla.kravchuk@lnu.edu.ua \\ http://orcid.org/0000-0003-4087-3562
}

\title{
„Gazeta Polska Bukowiny” jako źródło do badań współczesnej polszczyzny pisanej na Ukrainie
}

\section{Wprowadzenie: \\ odmiany polszczyzny na Ukrainie z perspektywy normatywnej}

Współczesna polszczyzna na Ukrainie istnieje w dwu najbardziej podstawowych odmianach: jako kod, którym posługują się przedstawiciele polskiej mniejszości narodowej ${ }^{1}$, oraz jako język obcy wyuczony przez obywateli Ukrainy niemających pol-

${ }^{1} \mathrm{~W}$ niniejszym tekście pozostajemy przy najbardziej tradycyjnym ujęciu terminologicznym współczesnej polszczyzny na Ukrainie jako „języka polskiej mniejszości narodowej” (dalej w tekście też: „język mniejszościowy”), unikając obecnych w najnowszych pracach określeń nawiązujących do kryterium genetycznego i będących tłumaczeniami angielskiego terminu heritage language: polszczyzna odziedziczona, polszczyzna dziedziczona, polszczyzna przodków, język pochodzenia. Tłumaczenia te nie są tożsame znaczeniowo i ich przydatność do opisu obecnej sytuacji polszczyzny na Ukrainie wymagałaby dodatkowych komentarzy (por. np. Dzięgiel, 2019, ss. 145-146). Nie używamy również terminu dzisiaj już historycznego - „polszczyzna południowokresowa”; unikamy obarczonego wieloznacznością wyrażenia „polszczyzna polonijna” (ale przytoczony przymiotnik pojawia się dalej w składzie terminu „norma polonijna”). Na określenie zaś użytkowników języka mniejszościowego używamy także terminu „Wspólnota komunikatywna” (na gruncie polskim pojawił się on w: Zabrocki, 1963, s. 194; Borawski,

This is an Open Access article distributed under the terms of the Creative Commons Attribution 3.0 PL License (creativecommons.org/licenses/by/3.0/pl/), which permits redistribution, commercial and noncommercial, provided that the article is properly cited. (C) The Author(s) 2021. 
skiego pochodzenia (język polski jako obcy). W odróżnieniu od odmiany pierwszej (a dokładniej - „odmian”, gdyż jest ona zróżnicowana ze względu na różne kryteria; zob. np. Dzięgiel, 2017), ukształtowanej historycznie, druga odmiana szczególnie się uwydatniła w czasach obecnych, a zwłaszcza w XXI wieku, gdy język polski stał się na całej Ukrainie bardzo popularnym i prestiżowym językiem obcym. Te dwie odmiany polszczyzny - teoretycznie rzecz ujmując - są „różnymi” językami polskimi, choć de facto cechuje je na ogół znaczne podobieństwo typowych odstępstw od językowej normy ogólnopolskiej, co spowodowane jest obecnie wpływami języka ukraińskiego lub rosyjskiego, aktywnie funkcjonującego na Ukrainie obok języka państwowego (w tym także oddziałującego na polszczyznę pośrednio - poprzez uzus ukraińskojęzyczny utrzymujący dużo rusycyzmów z różnych płaszczyzn językowych).

Jeśli zaś chodzi o mniejszościową polszczyznę pisaną, to - w ideale - powinna się ona zbliżać do standardu języka ogólnopolskiego, choć może też obejmować cechy językowe lokalne, podobnie jak niektóre regionalizmy lub całe ich typy dopuszczalne są w normie (użytkowej) polszczyzny ogólnej. Zadaniem niełatwym do zrealizowania jest dokładne określenie, które mianowicie typy „regionalizmów” mniejszościowych czy które konkretne jednostki „regionalne” mogą być uważane za pełnowartościowe składniki normy mniejszościowej - „normy polonijnej” (zob. termin w: Kucała, 1998), szczególnie w jej odmianie pisanej. Wszelkie próby ujęć preskryptywnych na temat normy polonijnej powinny być poprzedzane wnikliwą analizą materiału empirycznego, gdyż to nie zewnętrzny wobec języka badacz ma orzekać, co jest w nim „poprawne" i „sprawne” (w tym także „dopuszczalne”), a co sytuuje się „poniżej normy” - decydować o tym powinny wewnętrzne, samoregulujące mechanizmy językowe.

Jednym z najbardziej dostępnych źródeł umożliwiających obecnie podobne analizy jest język prasy polskiej mniejszości narodowej - mianowicie te teksty, które pisane są przez członków polonocentrycznych wspólnot komunikatywnych.

$\mathrm{Z}$ jednej strony, polszczyzna ta stanowi materiał, z którego można czerpać informację o obiektywnej normie polonijnej, z drugiej zaś - uchodzi ona za swoisty autorytet kulturalnojęzykowy, na którym, prawdopodobnie, wzorują się miejscowi czytelnicy. Te dwa aspekty kulturalnojęzykowe języka prasy mogą się kłócić ze sobą: obiektywny stan mniejszościowego języka (za)pisanego nie zawsze dorównuje wyidealizowanemu wyobrażeniu o wzorcu kulturalnojęzykowym. Najprostszym rozwiązaniem tej sprzeczności (notabene praktykowanym przez ostatnie lata $\mathrm{w}$ gazetach ukazujących się w języku polskim na Ukrainie) jest poddanie tekstów redakcji

1982, s. 385), z którym z kolei wiąże się zaproponowany przez Stanisława Dubisza (Dubisz, 1995) termin określający język wspólnoty: „język polonocentrycznych wspólnot komunikatywnych / komunikacyjnych poza granicami kraju", który jest neutralny i bardzo trafny, ale - jako wieloczłonowy - niezbyt wygodny w użyciu. Polszczyznę zaś ogólną i jego użytkownika określamy czasami w tym tekście za pomocą wyrażeń: „polszczyzna krajowa / w kraju” i „Polak krajowy”, które mogą się wydawać niezbyt udane (choć obecne w literaturze przedmiotu), jednak dobrze ujmują ważną dla wywodu opozycję znaczeniową. 
rodzimego użytkownika polszczyzny krajowej. W tym wypadku w polszczyźnie gazet pozostawać mogą szczątkowe tylko cechy swoistego języka mniejszościowego (a może ich nie pozostać wcale) i będzie ona służyć jako wzorzec „dobrej” polszczyzny (choć niepozbawionej, być może, idiolektalnych cech - np. niezgodnych z ogólną normą wzorcową, recesywnych itd. - native speakera redagującego teksty). Jednak czy wtedy będzie to jeszcze polszczyzna mniejszości - inna niż ta standardowa, ogólnopolska?

\section{2. „Gazeta Polska Bukowiny” jako źródło do badań językoznawczych}

\subsection{Charakterystyka ogólna periodyku i jego tekstów jako materiału badawczego}

„Gazeta Polska Bukowiny” stanowi jedno z nielicznych na Ukrainie źródeł najnowszej polszczyzny pisanej (ukazuje się od 2007 roku), prezentujących cenny materiał autentycznego języka członków polskiej wspólnoty komunikatywnej, a zatem może ona stanowić wdzięczny materiał do badań naukowych, o czym dokładniej będzie mowa dalej.

Periodyk ten przedstawiany jest w środowisku polskiej społeczności bukowińskiej jako kontynuator ukazującej się tutaj od 1883 roku $^{2}$ "Gazety Polskiej” (zob. o niej w: Bujak, 2013). Jak napisano w pierwszym numerze odrodzonej gazety: „Postanowiliśmy kontynuować tradycje starej «Gazety Polskiej», ale już w nowych warunkach jednoczącej się Europy” (1-2 (573-574) 2007; „Słowo do czytelników”, 2007). Gazeta - jako „pismo społeczne, gospodarcze i literacko-kulturalne” - jest organem organizacji społecznej o nazwie: Obwodowe Czerniowieckie Towarzystwo Kultury Polskiej im. Adama Mickiewicza. Druk periodyku jest dofinansowywany: najpierw ze środków otrzymanych z polskiego Ministerstwa Spraw Zagranicznych, później (od numeru 108 z 2016 roku) - ze środków Senatu RP, a następnie (od numerów 157-158 2020 roku) - ze środków Kancelarii Prezesa Rady Ministrów. Na początku dofinansowywanie odbywało się poprzez Fundację Pomoc Polakom na Wschodzie, a później (od 2014 roku) - przez Fundację Wolność i Demokracja. Gazeta należy do Federacji Mediów Polskich na Wschodzie (FMPnW) - organizacji zrzeszającej media polskie działające w krajach dawnego ZSRS, której członkowie spotykają się regularnie od 2013 roku. „Gazeta Polska Bukowiny” jest miesięcznikiem. Ukazały się do tej pory 154 numery. Periodyk dostępny jest w formacie pdf

${ }^{2}$ Gazeta wydawana była do wybuchu I wojny światowej, a w okresie międzywojennym ukazywała się nieregularnie do roku 1940 (Krasowska, 2006, s. 54, za: Biedrzycki, 1973, s. 98). 
na stronie internetowej Polonii bukowińskiej: http://bukpolonia.cv.ua/index.php/pl/ gazeta-polska-bukowiny, dostęp 09.10.2020 (Gazeta Polska Bukowiny, b.d.)3. Właśnie wolny dostęp internetowy umożliwia efektywne prowadzenie badań naukowych. W sieci zamieszczono 94 numery [26 z nich to numery łączone (podwójne), zatem ogółem istnieje dostęp do 68 plików gazety].

Każdy numer periodyku ma w miarę jednolitą strukturę, która jednak może być modyfikowana $\mathrm{w}$ zależności od aktualnych $\mathrm{w}$ odpowiednim czasie wydarzeń we wspólnocie bukowińskiej czy też w Polsce lub na Ukrainie. Tak więc na pierwszych stronach bywają zazwyczaj zamieszczane przedruki z mediów polskich dotyczące aktualności z Polski i ze świata czy też ważnych dla Polaków wydarzeń historycznych. W numerach ukazujących się w okresach świątecznych (Wielkanoc, Boże Narodzenie $)^{4}$ na pierwszej stronie publikuje się życzenia świąteczne, skierowane do wspólnoty komunikatywnej („rodaków”) w imieniu konsulów, redakcji, funkcjonariuszy z Polski, miejscowych władz ukraińskich (tłumaczenia na polski, czasem też teksty z życzeniami w języku ukraińskim) czy też poszczególnych, znanych w środowisku, przedstawicieli wspólnoty. Także na pierwszej stronie mogą być drukowane teksty gratulacyjne z okazji ważnych w życiu polonijnym jubileuszy. Na ostatniej zaś stronie gazety zamieszcza się gratulacje i życzenia, kierowane do poszczególnych osób, także kondolencje. Jeśli zaś chodzi o publikowane na ostatniej stronie ogłoszenia (np. konsularne lub inne), przygotowane przez krajowych Polaków, czy też np. przepisy kulinarne, małe teksty humorystyczne, teksty z „Kącika dla dzieci”, to - z przyczyn obiektywnych - nie nadają się one jako przedmiot analiz językowych, podobnie jak innego typu przedruki ze źródeł polskich. W gazecie mogą być też drukowane całe teksty w języku ukraińskim.

Materiałem zaś do badań są te publikacje, które pisane są po polsku przez członków wspólnoty. Są to najczęściej relacje z różnych wydarzeń w środowisku polonijnym, ewentualnie zawierające podziękowania za organizację konkretnych przedsięwzięć lub udział w nich. Publikowane są teksty z podziękowaniami za organizację świąt w oddziałach towarzystw polonijnych, wyjazdów do Polski (na wycieczki, szkoły letnie itd.), kierowanymi do konsulatu, sponsorów z Polski, wolontariuszy, nauczycieli, kierowników zespołów artystycznych itd. Co roku drukuje się teksty na temat odbywającego się latem dużego przedsięwzięcia kulturalnego - międzynarodowego festiwalu „Bukowińskie Spotkania”. Są teksty o konferencjach i seminariach naukowych przeprowadzanych na Uniwersytecie w Czerniowcach lub w innych placówkach. Zatem zakres tematyczny publikacji to zarówno historia, kultura i tradycje polskie, edukacja, nauka, religia, w tym - obowiązkowo - konkretne wydarzenia z Czerniowiec i okolic, jak i z życia całej społeczności polskiej na Ukrainie.

${ }^{3}$ Wiele numerów znajduje się także na stronie: https://kresy24.pl/archiwum-gazety-polskiej-bukowiny, dostęp 09.10.2020 (Archiwum „Gazety Polskiej Bukowiny”, b.d.).

${ }^{4} \mathrm{~Np}$. pierwsze numery listopadowe gazety zawierają zazwyczaj na pierwszej stronie informacje o obchodach Święta Niepodległości Polski na Ukrainie i w Polsce lub też odpowiednie teksty historyczne. 
Zarówno autorzy tych publikacji prasowych, jak i redakcja ${ }^{5}$ to przedstawiciele wspólnoty komunikatywnej - członkowie organizacji polonijnych w Czerniowcach i regionie, nauczyciele języka polskiego szkół sobotnich (niedzielnych), znane w środowisku osoby, jak i ludzie „zwykli”. Zatem polszczyzna periodyku jest reprezentatywna: w gazecie publikują przedstawiciele Polonii o zróżnicowanych kompetencjach językowych, przedstawiciele różnych środowisk i zawodów. W drukowanych tekstach zdarzają się tłumaczenia fragmentów wypowiedzi osób ukraińskojęzycznych, jednak i wtedy jest to polszczyzna - choć powstała w wyniku tłumaczenia przedstawicieli polonocentrycznej wspólnoty komunikatywnej.

Pewne wątpliwości metodologiczne wzbudzić może fakt, że polszczyzna „Gazety Polskiej Bukowiny”, jak zresztą każdej innej gazety, a w szczególności wydawanej w społeczności lokalnej, może - mimo zasygnalizowanej reprezentatywności, być naznaczona cechami idiolektu redaktorów lub innych osób, które do gazety pisują najczęściej. Zjawiska tego trudno uniknąć, ale ewentualnym tego rodzaju zarzutom można się sprzeciwiać, zwracając uwagę na pewną analogię. Otóż nie zaprzecza się obecnie faktowi, że ujawnienie cech polszczyzny poza granicami kraju - w ogóle może opierać się - w szczególności - na uwzględnianiu studiów przypadku (metoda w ostatnich czasach bardzo popularna, zob. np. Dębski \& Miodunka, 2016), gdy konkretny idiolekt staje się cennym materiałem składającym się na tworzenie ogólnego obrazu polszczyzny mniejszościowej. Tak samo idiolekty osób piszących do redakcji i samych jej członków składają się - naturalnie - na cechy językowe periodyku.

Ponadto warto zwrócić uwagę jeszcze na pewien aspekt analizowanej polszczyzny, tym razem - pragmalingwistyczny. Teksty prasy mniejszościowej są naukowo cenne jako pisane nie tylko PRZEZ kogoś, lecz także DLA kogoś - mianowicie dla innych przedstawicieli wspólnoty. Zatem $w$ badaniach prowadzonych na materiale języka gazet, szczególnie mniejszościowych, ważna jest perspektywa nie tylko nadawcy tekstu, lecz także jego odbiorcy. Interesujące może być zastanowienie się nad kształtowaniem świadomości językowej modelowego odbiorcy - również użytkownika języka mniejszościowego, na którego pisany tekst gazety najprawdopodobniej oddziałuje jako jeden z autorytetów. Szczególnie ważne jest to w warunkach (jak na współczesnej Bukowinie ukraińskiej), gdy przedstawiciele mniejszości, szczególnie użytkownicy tzw. „polszczyzny ogólnobukowińskiej” (zob. termin w: Krasowska, 2010, s. 182), nie używają języka polskiego zbyt aktywnie ${ }^{6}$. Znaczy to, że dyferencjalne

${ }^{5}$ Przez cały czas ukazywania się gazety (14 lat) zespół redakcyjny ulegał nieznacznym zmianom rotacyjnym. Składał się najpierw z dziewięciu, a później z ośmiu osób. Niezmienni przez cały ten czas pozostają redaktor naczelny oraz zastępca - osoby pełniące funkcje kierownicze w obwodowym towarzystwie polonijnym w Czerniowcach.

${ }^{6}$ Helena Krasowska pisze, że reprezentanci polszczyzny ogólnobukowińskiej posługują się nią rzadko i że nawet zebrania w Domu Polskim w Czerniowcach odbywają się przeważnie w języku ukraińskim (Krasowska, 2010, s. 182). 
na tle normy ogólnopolskiej typowe jednostki językowe będą w tej polszczyźnie jeszcze bardziej utrwalane, jeśli jej odbiorcami są czytelnicy autorytatywnego źródła językowego, jakim jest we wspólnocie mniejszościowej gazeta polska. A więc stawać się one będą trwałym składnikiem obiektywnie rozumianej polonijnej normy językowej. Wychwycenie tych właśnie jednostek odznaczających się dużą frekwencją i następnie ich analiza kulturalnojęzykowa, uwzględniająca różne (nie tylko uzualne) kryteria oceny faktów językowych, mogą dać materiał do refleksji nad możliwością bardziej liberalnego myślenia o normie odmian polszczyzny poza krajem.

Wstępna analiza tekstów „Gazety Polskiej Bukowiny” autorstwa członków wspólnoty komunikatywnej wykazała obecność swoistych, odbiegających od normy ogólnopolskiej, jednostek językowych na wszystkich płaszczyznach - od fleksji, poprzez składnię, słowotwórstwo, leksykę i frazeologię, po pragmatykę językową. Liczne są też odchylenia od normy w zakresie ortografii i interpunkcji, lecz nie wydają się one obiektem szczególnie zasługującym na analizę, gdyż reprezentują jedynie formę zapisu tekstu i związane są z (różnymi) możliwościami redakcyjnymi, a nie odzwierciedlają obiektywnego stanu funkcjonowania żywego języka (za)pisanego.

\subsection{Stan badań nad współczesną polszczyzną bukowińską i tekstami prasy polskojęzycznej na Ukrainie}

Dotychczasowe studia nad polszczyzną bukowińską na Ukrainie reprezentują wyniki zakrojonych na szeroką skalę badań (np. Feleszko, 1991, 2002; Krasowska, 2006, 2010; Krasowska i in., 2018)7, które jednak skupiają się na odmianie mówionej, przy czym z wyraźną dominacją analizy zagadnień leksykalnych nad gramatycznymi. Odmiana pisana reprezentowana $\mathrm{w}$ prasie polskojęzycznej $\mathrm{z}$ różnych regionów Ukrainy też nie została jeszcze wszechstronnie zbadana. Istnieje gruntowna monografia o prasie polskojęzycznej na Ukrainie sowieckiej, w której omówiono m.in. treść gazet ukazujących się w latach 1918-1939 (Dzięgiel, 2016a; Dzięgiel i in., 2016). O współczesnej prasie polskojęzycznej na Ukrainie i jej roli kulturotwórczej dla mniejszości polskiej pisze Wisława Szymczuk (Szymczuk, 2012), a analizę pod tym względem polskojęzycznej prasy południowoukraińskiej przedstawia - jako fragment szerokiego studium nad mniejszością polską w tym regionie - Helena Krasowska (Krasowska, 2012, ss. 214-220). Wymienione publikacje nie przedstawiają jednak badań lingwistycznych tych źródeł. Językoznawcze analizy proponuje Ewa Dzięgiel w artykułach o problematyce leksykalnej w języku prasy na Ukrainie sowieckiej (Dzięgiel, 2016b, 2016c). Zagadnieniom gramatycznym - tym razem prowadzonym już

7 Szerzej z literaturą przedmiotu oraz stanem badań nad mówioną polszczyzną bukowińską oraz kulturą regionu można zapoznać się w: Krasowska i in., 2018, ss. 13-17. 
na materiale języka prasy polskojęzycznej na Ukrainie, ukazującej się od czasów odzyskania niepodległości do roku 2014, poświęcona jest rozprawa doktorska Oksany Ohoriłko (Огорілко, 2014). Na materiale tekstów kilkuset numerów gazet z różnych regionów Ukrainy („Kurier Galicyjski”, „Gazeta Lwowska”, „Lwowskie Spotkania”, „Dziennik Kijowski”, „Gazeta Polska”, „Mozaika Berdyczowska”, „Polonia Charkowa") zbadano w niej odstępstwa od ogólnopolskiej normy składniowej - wzorcowej i użytkowej. W osobnym artykule Ohoriłko wymieniono kilka osobliwości fleksyjnych pojawiających się w tekstach tych gazet (Огорілко, 2009). Badania składniowe nad tekstem prasowym rozwija Ałła Krawczuk, skupiając się na nieuwzględnionym w doktoracie oraz artykułach Ohoriłko materiale właśnie interesującej nas „Gazety Polskiej Bukowiny”, ale ograniczając się do zagadnień realizacji w tekstach tego periodyku składniowych związków rządu (Krawczuk, 2019b). W wyniku przeprowadzonych analiz potwierdzono typowość i trwałość swoistego kształtu wielu jednostek składniowych, które przedstawiła Ohoriłko, ale pokazano też takie przykłady oraz całe typy odstępstw od składniowej normy wzorcowej i użytkowej w zakresie składni rządu, które nie były wcześniej analizowane. W ten sposób przekonujemy się, że „Gazeta Polska Bukowiny” daje badaczowi bogaty materiał empiryczny. W jeszcze innym artykule periodyk ten służy jako źródło do badań nad specyfiką grzeczności językowej w tekstach prasy (Krawczuk, 2019a), uwyraźniając i poszerzając zakres cech pragmalingwistycznych polszczyzny przedstawionych wcześniej na materiale tekstów innych gazet polskojęzycznych na Ukrainie (Krawczuk, 2012, 2013, 2014).

\subsection{Nowe perspektywy badań nad polszczyzną gazety bukowińskiej}

Nowe perspektywy badań nad językiem „Gazety Polskiej Bukowiny”, a na tej podstawie - także nad polszczyzną pisaną na Ukrainie - pojawiają się w związku z powstaniem elektronicznego korpusu tej gazety, opracowanego w ramach aplikacji Korpusomat - korpusomat.pl (Kieraś i in., 2018; Korpusomat, b.d.), która pozwala na tworzenie własnych korpusów, m.in. poprzez dodawanie publikacji ze stron internetowych. Korpusomat zawiera korpusy zarówno ogólnie dostępne (choć i mające swojego właściciela), jak i te o ograniczonym dostępie, stworzone na potrzeby konkretnych badan, którym jest wspomniany korpus gazety bukowińskiej, opracowany przez językoznawcę Andrzeja Moroza z Uniwersytetu Mikołaja Kopernika w Toruniu. Aktualnie korpus zawiera 393737 segmentów, istnieje możliwość zapoznania się z liczbą segmentów każdego numeru (w terminologii korpusowej - „tekstu”) gazety; ogólna liczba przedstawionych numerów- 62 (od 2007 do 2019 roku), korpus może być dalej uzupełniany. Możliwe jest wyszukiwanie leksemów (w tym nazw własnych), części mowy, form fleksyjnych, konstrukcji składniowych, jak również wyrażeń, którym przypisano określoną charakterystykę gramatyczną (czyli przedmiotem wyszukiwania nie musi 
być konkretna jednostka, a np. dowolne wyrażenie z przypisanymi cechami gramatycznymi). Zatem narzędzia Korpusomatu szczególnie wartościowe są dla badań nad składnią pisanej odmiany polszczyzny mniejszościowej - ze względu na możliwość wyszukiwarki odwoływania się w zapytaniach do cech składniowych wypowiedzeń. Tak więc np. wychwycone „ręcznie” w tekście prasy przykłady struktur składniowych, dyferencjalnych na tle normy ogólnopolskiej, można zweryfikować poprzez przeszukanie korpusu, uzyskując maksimum reprezentacji interesującego zjawiska składniowego, co umożliwia ocenę stopnia jego powszechności. Wyniki badań na materiale korpusu gazety mogą być zestawiane $\mathrm{z}$ danymi uzyskanymi w wyniku analizy korpusu języka polskiego w kraju (na podstawie Narodowego Korpusu Języka Polskiego - NKJP, http://nkjp.pl; NKJP, b.d.), co umożliwi otrzymanie informacji o tym, w jakim stopniu składnia tekstów pisanych polszczyzny mniejszościowej może korelować z faktycznymi (niekoniecznie zgodnymi z normą) użyciami składniowymi w języku ogólnopolskim. Taka perspektywa uchroni badacza polszczyzny na Ukrainie przed zawężeniem komparacji materiału tylko $\mathrm{z}$ faktami normy przedstawionymi w źródłach kodyfikacyjnych i umożliwi pokazanie, w jakim stopniu polszczyzna na Wschodzie koreluje z językiem realnie używanym przez Polaków w kraju. Ponadto analiza dwu korpusów może być owocna także $\mathrm{w}$ doprecyzowaniu statusu normatywnego niektórych jednostek językowych w samej polszczyźnie krajowej - tych mianowicie, które znajdują się w „strefach" wątpliwości normatywnych (pogranicza "poprawne - niepoprawne”). Np. wychodząc od wyraźnie interferencyjnej i jakoby niepoprawnej w tekście korpusu gazety bukowińskiej struktury z przymiotnikowym orzecznikiem w narzędniku typu Oczywistym jest, że..., ujawniamy, że również w NKJP zdarzają się podobne użycia narzędnikowe. $\mathrm{W}$ ten sposób odnaleziona typowa cecha składniowa polszczyzny na Ukrainie może pobudzić do poszukiwania jej odpowiedników formalnych w języku ogólnopolskim i dzięki temu niewykluczone będzie uzyskanie pełniejszych informacji o jej statusie normatywnym w polszczyźnie ogólnej. Pod tym względem interesujące też mogą być np. badania nad kształtem niektórych spójników zespolonych (np. nie tylko..., ale i) czy też nad elipsą łącznika w orzeczeniu imiennym.

\subsection{Materiał przykładowy: swoistość deklinacji rzeczownika w warunkach kontaktów językowych}

Na przykładzie poświadczonych swoistych cech fleksyjnych występujących w tekstach "Gazety Polskiej Bukowiny” przekonujemy się, że powielają one i utrwalają zjawiska specyficzne dla polszczyzny mniejszościowej ${ }^{8}$. Uzyskane metodą „ręcznego”

${ }^{8}$ Osobliwości deklinacji rzeczownika w pisanej polszczyźnie wileńskiej, realizowanej w tekstach powojennej prasy (do 1979 roku), dokładnie przeanalizowała Jolanta Mędelska (Mędelska, 2000, 2001). W badaniach nad polszczyzną mniejszościową na Ukrainie deklinację rzeczownika na szerszą skalę 
wyszukiwania formy deklinacji rzeczownika (bez weryfikacji korpusowej ${ }^{9}$ ), odmienne od ogólnopolskich, stanowią 93 jednostki, które mogą kształtować większe typy jednorodnych zjawisk.

Cechą dość wyrazistą jest ucieczka w nieodmienność niektórych klas rzeczowników. Są to m.in. nazwiska zakończone na -o, które w normie wzorcowej polszczyzny ogólnej (ale nieobowiązkowo w uzusie) są odmieniane przez przypadki, np. [...] jednego z najzdolniejszych uczniów Czerniowieckiej Szkoły Muzycznej Nr 2 Denysa Zarubajko ${ }^{10}$ (41-42 (623-624) 2010); poinformowat Ryszarda Legutko (15-16 (587-588) 2008); z profesorem Kazimierzem Feleszko (92 (675) 2014). W języku ukraińskim męskie nazwiska zakończone na -o są odmieniane według paradygmatu męskiego, w rosyjskim - nie są odmieniane w ogóle, a więc normatywne polskie deklinowanie według wzorca żeńskiego typu Zarubajko - Zarubajki, Zarubajce itd. jest dla użytkownika polszczyzny w otoczeniu ukraińskojęzycznym nietypowe. Dodajmy, że nieodmienność podtrzymywana może być uzusem ogólnopolskim lub po prostu jest skutkiem ekonomii wysiłku. Nieodmienny we współczesnym języku ukraińskim (i rosyjskim) jest formalny odpowiednik polskiego wyrazu radio ${ }^{11}$, stąd (mogący też być skutkiem ekonomiczności) przykład: w radio Eska Rock (95 (678) 2015). Na wzór niektórych nieodmienianych w języku ukraińskim zapożyczeń na -o pozostawia się bez odmiany leksem dyktando: udział w Dyktando (133 (715) 2018).

$\mathrm{W}$ deklinacji rzeczownika zarejestrowano odstępstwa od normy we wszystkich, oprócz narzędnika i miejscownika liczby mnogiej, przypadkach, które dalej przedstawiamy głównie w kolejności paradygmatu przypadkowego (poza kilkoma wypadkami synkretyzmów).

przedstawiono na materiale gwarowym (np. Cechosz, 2001; Dzięgiel, 2003), pokazano ją także w języku współczesnej młodzieży polskiego pochodzenia (Зелінська, 2018; Король, 2009). Nie zostały jednak pod tym względem zbadane teksty współczesnych gazet mniejszości polskiej na Ukrainie (z wyjątkiem wspomnianej już prezentacji nielicznych przykładów w: Огорілко, 2009). Tymczasem uwzględnienie szerzego materiału pochodzącego ze współczesnych tekstów pisanych, w tym prasowych, tworzonych przez osoby polskiego pochodzenia na Ukrainie, pozwoli na ukazanie - z jednej strony - najbardziej typowych i trwałych odstępstw od normy ogólnopolskiej w zakresie fleksji rzeczownika w polszczyźnie na Ukrainie, a z drugiej - zjawisk charakterystycznych właśnie dla współczesnej mniejszościowej polszczyzny pisanej.

${ }^{9}$ W przyszłości można jednak te badania uzupełnić, a także zestawić niektóre ujawnione dotychczas przykłady (np. te reprezentujące dopełniacz lp rzeczowników męskich o wahaniach końcówkowych $-a,-u$ ) z danymi ogólnopolskiego NKJP.

${ }^{10}$ Dalej - ze względu na ograniczenia objętościowe niniejszej publikacji - przykłady będą przytaczane w kontekstach minimalnych, bez każdorazowego zapisywania wielokropków w nawiasach kwadratowych: [...] wskazujących na nieprzytaczanie kontekstu szerszego. Pojawiające się w dalszych przykładach odstępstwa od normy inne niż te związane z deklinacją rzeczownika pozostawia się bez komentarzy.

${ }^{11} \mathrm{~W}$ ukraińskiej normie gramatycznej początku XX wieku leksem padio miał formę narzędnikową padioм, wyjątkowo - na tle innych form przypadkowych - przybierającą końcówkę inną niż -o (Голоскевич, 1929, s. 461). 
Dopełniacz lp rzeczowników męskich jest problematyczny w aspekcie poprawnościowym także dla rodzimych użytkowników polszczyzny w kraju, gdyż obciąża pamięć licznymi wyjątkami. Semantyczne lub czysto leksykalne uzasadnienie wyboru końcówek tego przypadka jest, tak samo jak w języku polskim, także w językach wschodniosłowiańskich. Formalne odpowiedniki trzech poniższych leksemów polskich mają $\mathrm{w}$ języku ukraińskim końcówkę - $u$, czym można motywować pojawienie się tej końcówki w wyrazach polskich: Trafić do światu duchownego (41-42 (623-624) 2010); tajemnica przygotowania seru regionalnego (136-137 (718-719) 2018); według tradycyjnego scenariuszu (136-137 (718-719) 2018). W następujących zaś przykładach normatywne odpowiedniki ukraińskie spowodować interferencji nie mogły: obok ratuszu w Gdańsku (134-135 (716-717) 2018); Waleryj Dymszyc $z$ Sankt-Petersburgu (136-137 (718-719) 2018); tego festiwala (136-137 (718-719) 2018); przygotowania do festyna (36-37 (618-619) 2010).

W celowniku lp rzeczowników męskich obserwuje się użycie morfemu fleksyjnego - $u$ pod wpływem odpowiedniej końcówki w języku ukraińskim, występującej w nim częściej niż możliwa w tym przypadku końcówka o wariantach -ovi / -evi (zalecana zwłaszcza do użycia w nazwach osobowych): składam serdeczne podziękowania [...] Arturowi Oskwarku (126 (709) 2017); Paktu Ribbentrop-Mołotow - 70 lat (26-27 (608-609) 2009); poświęconej Dniu Niepodległości Ukrainy (136-137 (718-719) 2018).

W celowniku lp rzeczowników żeńskich, których temat kończy się spółgłoską stwardniałą, obserwujemy końcówkę - $e$ - taką, jaka występuje po odpowiednich tematach w wyrazach języka rosyjskiego (w języku ukraińskim jest -i), np. poświęcony 70-j rocznice (28-29 (610-611) 2009). Niemniej konkluzja o obowiązkowym bezpośrednim wpływie leksemów rosyjskich byłaby zbyt pochopna. Jeśli w przypadku osób władających językiem rosyjskim takie tłumaczenie jest naturalne, to dla osób nieużywających języka rosyjskiego (których polszczyzna również ma tę typową na Ukrainie cechę) stosowanie takich form wyjaśnić można interferencją wewnętrzną - wyrównaniem form do ogólniejszej końcówki -e z paradygmatu twardotematowego, gdyż spółgłoski środkowojęzykowe brzmią jak spółgłoski twarde, a nie miękkie. Osłuchanie się z językiem rosyjskim jest czynnikiem podtrzymującym to odchylenie od normy.

Takie samo zjawisko obserwujemy w synkretycznym z celownikiem miejscowniku żeńskich rzeczowników miękkotematowych. Ze względu na większą w języku frekwencyjność form miejscownika w porównianiu $\mathrm{z}$ formami celownika, w materiale gazety przykładów miejscownikowych jest więcej: napis na tablice upamiętniającej (23-24 (605-606) 2009); po prace przy pomniku młodzież położyła koszyki (36-37 (618-619) 2010); leży na granice (28-29 (610-611) 2009); udział w uroczystej Msze Świętej 30 (612) 2009); odwiedzili cmentarz w Rarancze (90 (673) 2014); podczas występów festiwalowych $w$ Wiżnice (23-24 (605-606) 2009); Konsulat Generalny RP $w$ Winnice (147-148, (729-730) 2019). 
Biernik lp rzeczowników żeńskich jest reprezentowany kilkukrotnymi użyciami wyrazów kończących się na - a z biernikową końcówką - e zamiast -ę, np. przyjechat na Bukowine (90 (673) 2014), może to jednak być kwestia ortografii, a nie fleksji. Rzeczownik pani (formalnie nieodmienny w języku ukraińskim) pozostaje w formie na -i: Mile wspominam pani Dominike (123-124 (706-707) 2017). Wyraz państwo oznaczający małżeństwo bywa używany w formie równej mianownikowi - tak, jak odpowiedni rzeczownik rodzaju nijakiego w znaczeniu politycznym: pozdrawiamy [...] Państwo Reginę i Tomasza Kałuskich (28-29 (610-611) 2009).

W narzędniku lp nie występują w polszczyźnie końcówki wspólnofunkcyjne, dlatego nie jest on przypadkiem problematycznym. Zarejestrowane odstępstwo od normy w zakresie (nie)użycia narzędnika w przykładzie Koniec lipca przyniósł 80. urodziny dla Tamary Sewerniuk [...]. Jest członkini ukraińskiego związu pisarzy i dziennikarzy Ukrainy (161 (742) 2020) można wytłumaczyć albo jako problem znajomości składni orzecznika; albo jako ucieczkę w nieodmienność rzeczowników na -i (por. wcześniejszy przykład biernikowy Mile wspominam pani Dominikę); wreszcie może to być zwykła literówka.

W miejscowniku lp rzeczowników męskich mamy przykład $w$ Domie Polskim odbyła się wystawa (112-113 (695-696) 2016), który może być skutkiem interferencji zewnętrznej (ros. $v$ dome, ukr. $v$ domi) lub też wewnętrznej (nieuwzględnienie wyjątków) czy też polskim archaizmem.

W wołaczu lp rzeczowników męskich nieżywotnych występują formy równe mianownikowi: Kraków, dziękujemy tobie! (15-16 (587-588) 2008); Mówimy, dowidzenia Festyn i do mitego zobaczenia w przyszłym roku! (36-37 (618-619) 2010). Podobne formy mogą przybierać i nazwy antroponimiczne: Wielce Szanowny Pan Jan GUŁA! (133 (715) 2018); Szanowny Pan Prezes [...]! (32-33 (614-615) 2010). Formy te nawiązują do języka rosyjskiego, w którym funkcję wołacza przejął mianownik. $\mathrm{W}$ potocznym języku ukraińskim, niezgodnym z normą, formy wołacza równe mianownikowi też są możliwe.

Mianownik Im przedstawiony jest formami, pozbawionymi - najprawdopodobniej (w sytuacji na Bukowinie) pod wpływem języków wschodniosłowiańskich - wykładników męskoosobowości w rzeczownikach twardotematowych, jak np. profesory Uniwersytetu (87 (670) 2014).

W miękkotematowych rzeczownikach rodzaju męskiego i żeńskiego typową cechą jest używanie końcówki - $i$ zamiast -e lub - po tematach stwardniałych - $-y$ zamiast -e: Gości odwiedzili Uniwersytet (90 (673) 2014); sa jeszcze dwa ottarzy (41-42 (623-624) 2010); byty lekcji (28-29 (610-611) 2009); towarzyszące jej zwyczaje i tradycji (9-10 (581-582) 2008); serdeczne gratulacji (92 (675) 2014). Przyczyną jest raczej fleksyjna interferencja zewnętrzna (w językach wschodniosłowiańskich nie występuje w mianowniku liczby mnogiej końcówka -e), choć nie można też wykluczać efektu procesu fonetycznego: zwężenia $e$ do $i$ pod wpływem wymowy wschodniosło- 
wiańskiej, co dotyczy również innych przypadków, w których występuje końcówka $-i$ zamiast $-e$.

To samo odchylenie od normy obserwujemy w synkretycznym z mianownikiem wołaczu lm: Witamy Was, Drodzy Nauczycieli (89 (672) 2014) i bierniku lm: Przedstawiamy niektóre fotografii (136-137 (718-719) 2018); przeżyłem piękne chwili (41-42 (623-624) 2010).

W dopelniaczu lm odstępstwa od normy pojawiają się w trudnych w odmianie leksemach oczy, Niemcy: studenci dotykali oczy, nosów i ust (28-29 (610-611) 2009); około 100 motocyklistów z Polski, Niemczech, ze Stanów Zjednoczonych Ameryki (89 (672) 2014).

Celownik Im reprezentuje forma z końcówką -ą zamiast -om spowodowana chyba odwzorowaniem wersji wymawianiowej: zaprezentowat się z częścia artystyczna poświęcona pastoratkom i kolędą z Polski i Bukowiny (129-130 (711-712) 2018).

$\mathrm{W}$ bierniku lm mamy zewnątrzinterferencyjne - równe dopełniaczowi - formy rzeczowników oznaczających istoty żywe (ale nie męskoosobowych), np. przygotowany przez naszych kobiet (36-37 (618-619) 2010); powitani przez zwierzatek domowych (154 (736) 2020): w języku ukraińskim, jak i rosyjskim, biernik równy dopełniaczowi występuje u rzeczowników wszystkich rodzajów oznaczających istoty żywe.

\section{Wnioski}

„Gazeta Polska Bukowiny” - jako źródło do badań współczesnej prasowej polszczyzny mniejszościowej, przedstawiające zwarty materiał językowy z całego prawie ostatniego piętnastolecia - zawiera cenne dane składające się na ogólny obraz sytuacji najnowszego polskiego języka pisanego na Ukrainie. Publikując teksty opracowane, a nie wypowiedzi doraźne, poświadcza ona utrwalone odstępstwa od normy ogólnopolskiej z różnych płaszczyzn języka, od gramatyki do pragmatyki. Jako jeden z autorytetów kulturalnojęzykowych we wspólnocie, polszczyzna ta może sprzyjać dalszemu utrwaleniu typowych cech swoistych języka polskiego na Ukrainie, decydując o kształcie realnej normy polonijnej. Odbiegające od normy ogólnopolskiej jednostki językowe mają wyraźne ślady wpływów wschodniosłowiańskich ${ }^{12}$ (przy czym czasami mogą one jednocześnie się zgadzać z błędnymi formami uzualnymi polszczyzny ogólnej). Jest to przede wszystkim język ukraiński, może też być rosyjski - oddziałujący bezpośrednio lub poprzez swoją obecność w uzusie ukraińskojęzycznym; nie ujawniono w języku prasy możliwych w tym regionie cech motywowanych językiem rumuńskim. Na przykładzie przytoczonych cech dyferencjalnych deklinacji

${ }^{12}$ Choć nie można też całkowicie wykluczyć możliwości zachowania archaicznych cech polszczyzny południowokresowej, która historycznie miała wpływ na kształtowanie języka polskiego na Bukowinie. 
rzeczownika można obserwować, oprócz dominujących wpływów zewnętrznych, także wyniki interferencji wewnętrznej, kiedy to, wskutek dążeń ekonomizujących, regułę „węższą” podporządkowuje się regule ogólniejszej. W zakresie deklinacji rzeczownikowej najczęściej poświadczonymi jednostkami są te, w których odbiegająca od normy ogólnopolskiej końcówka występuje po tematach miękkich, a w szczególności tych zakończonych spółgłoską stwardniałą. Ujawnione fakty fleksji rzeczownikowej nie uzyskują raczej aprobaty normatywnej (zresztą nie są one w tekście prasowym na tyle liczne, by mogły „aspirować” do przynależności do realnej normy polszczyzny pisanej na Ukrainie). Natomiast swoiste jednostki składniowe są prezentowane $\mathrm{w}$ tekstach analizowanego periodyku na skalę bardzo szeroką i stanowią interesujący materiał do badań nie tylko poświadczających typy odstępstw od normy, lecz także będących przyczynkiem do nowego spojrzenia na realną polonijną normę składniową. Podobne możliwości badawcze daje także warstwa jednostek grzecznościowych w tekstach „Gazety Polskiej Bukowiny”. Powstanie elektronicznego korpusu tego periodyku pozwoli na doprecyzowanie statystyk oraz ujawnienie proporcji między jednostkami dyferencjalnymi a tymi zgodnymi z normą ogólnopolską, szczególnie w zakresie składni, słownictwa, etykiety językowej. Zestawienie materiałów tego korpusu z zawartością korpusu języka polskiego w kraju może ujawnić cenne fakty językowe nadające się do analiz nad chwiejnością normy składniowej w polszczyźnie ogólnej [jak np. kształt niektórych spójników zespolonych, wahania w zakresie przypadka (mianownik/narzędnik) przyczasownikowej frazy przymiotnikowej, elipsa tzw. łącznika w orzeczeniu imiennym].

Reasumując: „Gazeta Polska Bukowiny” zawiera wartościowy materiał do badań naukowych, gdyż dokumentuje pisaną odmianę najnowszej polszczyzny mniejszościowej (podczas gdy w literaturze dominują badania odmiany mówionej); ze względu na zróżnicowanie autorów publikacji daje materiał w pełni reprezentatywny; umożliwia poza tym badania z perspektywy nie tylko nadawcy, lecz także odbiorcy. Dokumentując dyferencjalne na tle normy ogólnopolskiej i motywowane kontaktami językowymi zjawiska polszczyzny mniejszości polskiej (pozyskiwane metodą kontrastywną), przynosi materiał do badań nad kształtem normy polonijnej, a aplikacja Korpusomat udostępnia rozszerzenie możliwości badawczych dzięki zastosowaniu metody korpusowej.

\section{Bibliografia}

Archiwum „Gazety Polskiej Bukowiny”. (b.d.). Kresy24.pl. https://kresy24.pl/archiwum-gazety-polskiej-bukowiny/

Biedrzycki, E. (1973). Historia Polaków na Bukowinie. Państwowe Wydawnictwo Naukowe. 
Borawski, S. (1982). O potrzebach historii języka polskiego II. Czas powstania polskiego języka literackiego. Poradnik Językowy, 1982(6), 368-386.

Bujak, J. (2013). Gazeta Polska 1883-1914. Towarzystwo Słowaków w Polsce.

Cechosz, I. (2001). Polska gwara Oleszkowiec na Podolu: Fleksja imienna i werbalna. Wydawnictwo Naukowe DWN.

Dębski, R., \& Miodunka, W. T. (Red.). (2016). Bilingwizm polsko-obcy dziś: Od teorii i metodologii badań do studiów przypadków: Monografia zbiorowa. Księgarnia Akademicka.

Dubisz, S. (1995). Metoda kontrastywna w badaniach przemian języka polonocentrycznych wspólnot komunikatywnych poza granicami kraju. W S. Gajda (Red.), Języki słowiańskie 1945-1995: Gramatyka - leksyka - odmiany (ss. 37-46). Uniwersytet Opolski.

Dzięgiel, E. (2003). Polszczyzna na Ukrainie: Sytuacja językowa w wybranych wsiach chłopskich $i$ szlacheckich. Wydawnictwo Naukowe Semper.

Dzięgiel, E. (Red.). (2016a). Prasa polskojęzyczna w początkach sowietyzacji Ukrainy: Wybór źódeł. https://prasapolukr.ijp.pan.pl/

Dzięgiel, E. (2016b). Przymiotnik czerwony w polskojęzycznej prasie wydawanej na Ukrainie sowieckiej w latach 20. i 30. XX wieku. Acta Baltico-Slavica, 40, 206-231. https://doi. org/10.11649/abs.2016.010

Dzięgiel, E. (2016c). Zmienne losy przymiotników sowiecki i radziecki w polskojęzycznej prasie wydawanej na Ukrainie sowieckiej w latach dwudziestych i trzydziestych XX wieku. Język Polski, 96(4), 108-118.

Dzięgiel, E. (2017). Odmiany terytorialne i społeczne współczesnego języka polskiego na Ukrainie. LingVaria, 12(24), 199-210. https://doi.org/10.12797/LV.12.2017.24.13

Dzięgiel, E. (2019). Polszczyzna w transmisji międzypokoleniowej w rodzinach jednolitych i mieszanych we Lwowskiem. Acta Baltico-Slavica, 43, 143-160. https://doi.org/10.11649/ abs. 2019.013

Dzięgiel, E., Czarnecka, K., Kowalska, D. A., \& Yanushevska, L. (2016). Polskojęzyczna prasa na Ukrainie sowieckiej w latach 1918-1939: Przegląd tytułów i treści. Instytut Języka Polskiego Polskiej Akademii Nauk.

Feleszko, K. (1991). Język polski na Bukowinie do roku 1945: Zarys problematyki. W J. Rieger \& W. Werenicz (Red.), Studia nad polszczyzną kresowa (T. 6, ss. 7-28). Zakład Narodowy im. Ossolińskich.

Feleszko, K. (2002). Bukowina moja miłość: Język polski na Bukowinie Karpackiej do 1945 roku (A. Żor, Red.; T. 1). Instytut Slawistyki Polskiej Akademii Nauk (Slawistyczny Ośrodek Wydawniczy).

Gazeta Polska Bukowiny. (b.d.). Сайт буковинської Полоніï. http://bukpolonia.cv.ua/index. $\mathrm{php/pl/gazeta-polska-bukowiny}$

Kieraś, W., Kobyliński, Ł., \& Ogrodniczuk, M. (2018). Korpusomat - a tool for creating searchable morphosyntactically tagged corpora. Computational Methods in Science and Technology, 24(1), 21-27. https://doi.org/10.12921/cmst.2018.0000005

Korpusomat. (b.d.). https://korpusomat.pl 
Krasowska, H. (2006). Górale polscy na Bukowinie Karpackiej: Studium socjolingwistyczne i leksykalne. Instytut Slawistyki Polskiej Akademii Nauk (Slawistyczny Ośrodek Wydawniczy); Towarzystwo Naukowe Warszawskie.

Krasowska, H. (2010). Język Polaków na Bukowinie Karpackiej. Studia z Filologii Polskiej i Słowiańskiej, 45, 175-186. https://doi.org/10.11649/sfps.2010.010

Krasowska, H. (2012). Mniejszość polska na południowo-wschodniej Ukrainie. Instytut Slawistyki Polskiej Akademii Nauk (Slawistyczny Ośrodek Wydawniczy).

Krasowska, H., Pokrzyńska, M., \& Suchomłynow, L. (2018). Świadectwo zanikającego dziedzictwa: Mowa polska na Bukowinie: Rumunia - Ukraina. Instytut Slawistyki Polskiej Akademii Nauk.

Krawczuk, A. (2012). Osobliwości etykiety językowej we współczesnej polskojęzycznej prasie na Ukrainie. W A. Burzyńska-Kamieniecka, M. Misiak, \& J. Kamieniecki (Red.), Kresowe dziedzictwo: Studia z języka, historii i kultury (ss. 219-229). Oficyna Wydawnicza ATUT.

Krawczuk, A. (2013). Struktury referujące z wyrazami pan / pani w polskojęzycznej prasie na Ukrainie: grzeczność czy niegrzeczność? Acta Universitatis Lodziensis: Kształcenie Polonistyczne Cudzoziemców, 20, 119-129.

Krawczuk, A. (2014). Norma językowa w prasie polskojęzycznej na Ukrainie (wybrane aspekty). Postscriptum Polonistyczne, 2014(2(14)), 325-354.

Krawczuk, A. (2019a). Specification of selected honorifics in relation to the general Polish standard in the written Polish as a heritage language in Ukraine (using the material of the Polish-language „Gazeta Polska Bukowiny” periodical). Acta Universitatis Lodziensis: Ksztatcenie Polonistyczne Cudzoziemców, 26, 311-327. https://doi.org/10.18778/0860-6587.26.22

Krawczuk, A. (2019b). Związki rządu we współczesnej odziedziczonej polszczyźnie pisanej na Ukrainie na tle języka ogólnopolskiego. W M. Gębka-Wolak \& A. Krawczuk (Red.), Z bliska i z daleka: Język polski w badaniach językoznawców lwowskich i toruńskich (ss. 79-102). Wydawnictwo Naukowe Uniwersytetu Mikołaja Kopernika.

Kucała, M. (1998). O polonijnych normach językowych. Prace Filologiczne, 43, 287-294.

Mędelska, J. (2000). Język polskiej prasy wileńskiej (1945-1979): T. 2. Lata 1945-1959. Wydawnictwo Uczelniane Wyższej Szkoły Pedagogicznej.

Mędelska, J. (2001). Język polskiej prasy wileńskiej (1945-1979): T. 3. Lata 1960-1979: Cz. 1. Fonetyka, słowotwórstwo, fleksja, składnia. Wydawnictwo Uczelniane Akademii Bydgoskiej im. Kazimierza Wielkiego.

Narodowy Korpus Języka Polskiego [NKJP]. (b.d.). http://nkjp.pl

Słowo do czytelników. (2007, wrzesień). Gazeta Polska Bukowiny, 2007(1-2), 1. http://bukpolonia.cv.ua/images/gazetapolskabukowiny/2007/2007_N1-2.pdf

Szymczuk, W. (2012). Prasa mniejszości polskiej na Ukrainie. Europejskie Centrum Edukacyjne.

Zabrocki, L. (1963). Wspólnoty komunikatywne w genezie i rozwoju języka niemieckiego: Cz. 1. Prehistoria języka niemieckiego. Ossolineum. 
Голоскевич, Г. (1929). Правописний словник (за нормами украӥнського правопису Всеукраїнськоӥ Академї Наук). https://shron1.chtyvo.org.ua/Holoskevych_Hryhorii/Pravopysnyi_slovnyk.pdf

Зелінська, М. (2018). Комунікативна компетенція молодих носіїв польської мови західних областей Украӥни. Посвіт.

Король, Л. (2009). Регіональні особливості словозміни польських іменників та прикметників (на матеріалі питальника для учнів шкіл міста Львова з польською мовою викладання). Проблеми слов'янознавства, 58, 176-183.

Огорілко, О. (2009). Особливості іменникової та прикметникової словозміни в текстах польськомовної преси України. Компаративні дослідження слов'янських мов та літератур, $10,130-137$.

Огорілко, О. (2014). Синтаксичні особливості текстів сучасної польськомовної преси в Україні [Niepublikowana rozprawa doktorska]. Львівський національний університет імені Івана Франка.

\section{Bibliography (Transliteration)}

Archiwum "Gazety Polskiej Bukowiny”. (n.d.). Kresy24.pl. https://kresy24.pl/archiwum-gazety-polskiej-bukowiny/

Biedrzycki, E. (1973). Historia Polaków na Bukowinie. Państwowe Wydawnictwo Naukowe.

Borawski, S. (1982). O potrzebach historii języka polskiego II. Czas powstania polskiego języka literackiego. Poradnik Językowy, 1982(6), 368-386.

Bujak, J. (2013). Gazeta Polska 1883-1914. Towarzystwo Słowaków w Polsce.

Cechosz, I. (2001). Polska gwara Oleszkowiec na Podolu: Fleksja imienna i werbalna. Wydawnictwo Naukowe DWN.

Dębski, R., \& Miodunka, W. T. (Eds.). (2016). Bilingwizm polsko-obcy dziś: Od teorii i metodologii badań do studiów przypadków: Monografia zbiorowa. Księgarnia Akademicka.

Dubisz, S. (1995). Metoda kontrastywna w badaniach przemian języka polonocentrycznych wspólnot komunikatywnych poza granicami kraju. In S. Gajda (Ed.), Języki słowiańskie 1945-1995: Gramatyka - leksyka - odmiany (pp. 37-46). Uniwersytet Opolski.

Dzięgiel, E. (2003). Polszczyzna na Ukrainie: Sytuacja językowa w wybranych wsiach chłopskich $i$ szlacheckich. Wydawnictwo Naukowe Semper.

Dzięgiel, E. (Ed.). (2016a). Prasa polskojęzyczna w początkach sowietyzacji Ukrainy: Wybór źródeł. https://prasapolukr.ijp.pan.pl/

Dzięgiel, E. (2016b). Przymiotnik czerwony w polskojęzycznej prasie wydawanej na Ukrainie sowieckiej w latach 20. i 30. XX wieku. Acta Baltico-Slavica, 40, 206-231. https://doi. org/10.11649/abs.2016.010

Dzięgiel, E. (2016c). Zmienne losy przymiotników sowiecki i radziecki w polskojęzycznej prasie wydawanej na Ukrainie sowieckiej w latach dwudziestych i trzydziestych XX wieku. Język Polski, 96(4), 108-118. 
Dzięgiel, E. (2017). Odmiany terytorialne i społeczne współczesnego języka polskiego na Ukrainie. LingVaria, 12(24), 199-210. https://doi.org/10.12797/LV.12.2017.24.13

Dzięgiel, E. (2019). Polszczyzna w transmisji międzypokoleniowej w rodzinach jednolitych i mieszanych we Lwowskiem. Acta Baltico-Slavica, 43, 143-160. https://doi.org/10.11649/ abs.2019.013

Dzięgiel, E., Czarnecka, K., Kowalska, D. A., \& Yanushevska, L. (2016). Polskojęzyczna prasa na Ukrainie sowieckiej w latach 1918-1939: Przegląd tytułów i treści. Instytut Języka Polskiego Polskiej Akademii Nauk.

Feleszko, K. (1991). Język polski na Bukowinie do roku 1945: Zarys problematyki. In J. Rieger \& W. Werenicz (Eds.), Studia nad polszczyzną kresowa (Vol. 6, pp. 7-28). Zakład Narodowy im. Ossolińskich.

Feleszko, K. (2002). Bukowina moja miłość: Język polski na Bukowinie Karpackiej do 1945 roku (A. Żor, Ed.; Vol. 1). Instytut Slawistyki Polskiej Akademii Nauk (Slawistyczny Ośrodek Wydawniczy).

Gazeta Polska Bukowiny. (n.d.). Saĭt bukovyns'koï Poloniï. http://bukpolonia.cv.ua/index.php/ $\mathrm{pl}$ /gazeta-polska-bukowiny

Holoskevych, H. (1929). Pravopysnyı̆ slovnyk (za normamy ukraïns'koho pravopysu Vseukraïns'koï Akademiï Nauk). https://shron1.chtyvo.org.ua/Holoskevych_Hryhorii/Pravopysnyi_ slovnyk.pdf

Kieraś, W., Kobyliński, Ł., \& Ogrodniczuk, M. (2018). Korpusomat - a tool for creating searchable morphosyntactically tagged corpora. Computational Methods in Science and Technology, 24(1), 21-27. https://doi.org/10.12921/cmst.2018.0000005

Korol', L. (2009). Rehional'ni osoblyvosti slovozminy pol's'kykh imennykiv ta prykmetnykiv (na materiali pytal'nyka dlia uchniv shkil mista L'vova z pol's'koiu movoiu vykladannia). Problemy slov'ianoznavstva, 58, 176-183.

Korpusomat. (n.d.). https://korpusomat.pl

Krasowska, H. (2006). Górale polscy na Bukowinie Karpackiej: Studium socjolingwistyczne i leksykalne. Instytut Slawistyki Polskiej Akademii Nauk (Slawistyczny Ośrodek Wydawniczy); Towarzystwo Naukowe Warszawskie.

Krasowska, H. (2010). Język Polaków na Bukowinie Karpackiej. Studia z Filologii Polskiej i Słowiańskiej, 45, 175-186. https://doi.org/10.11649/sfps.2010.010

Krasowska, H. (2012). Mniejszość polska na południowo-wschodniej Ukrainie. Instytut Slawistyki Polskiej Akademii Nauk (Slawistyczny Ośrodek Wydawniczy).

Krasowska, H., Pokrzyńska, M., \& Suchomłynow, L. (2018). Świadectwo zanikającego dziedzictwa: Mowa polska na Bukowinie: Rumunia - Ukraina. Instytut Slawistyki Polskiej Akademii Nauk.

Krawczuk, A. (2012). Osobliwości etykiety językowej we współczesnej polskojęzycznej prasie na Ukrainie. In A. Burzyńska-Kamieniecka, M. Misiak, \& J. Kamieniecki (Eds.), Kresowe dziedzictwo: Studia z języka, historii i kultury (pp. 219-229). Oficyna Wydawnicza ATUT.

Krawczuk, A. (2013). Struktury referujące z wyrazami pan / pani w polskojęzycznej prasie na 
Ukrainie: grzeczność czy niegrzeczność? Acta Universitatis Lodziensis: Kształcenie Polonistyczne Cudzoziemców, 20, 119-129.

Krawczuk, A. (2014). Norma językowa w prasie polskojęzycznej na Ukrainie (wybrane aspekty). Postscriptum Polonistyczne, 2014(2(14)), 325-354.

Krawczuk, A. (2019a). Specification of selected honorifics in relation to the general Polish standard in the written Polish as a heritage language in Ukraine (using the material of the Polish-language "Gazeta Polska Bukowiny" periodical). Acta Universitatis Lodziensis: Ksztatcenie Polonistyczne Cudzoziemców, 26, 311-327. https://doi.org/10.18778/0860-6587.26.22

Krawczuk, A. (2019b). Związki rządu we współczesnej odziedziczonej polszczyźnie pisanej na Ukrainie na tle języka ogólnopolskiego. In M. Gębka-Wolak \& A. Krawczuk (Eds.), Z bliska i z daleka: Język polski w badaniach językoznawców lwowskich i toruńskich (pp. 79-102). Wydawnictwo Naukowe Uniwersytetu Mikołaja Kopernika.

Kucała, M. (1998). O polonijnych normach językowych. Prace Filologiczne, 43, 287-294.

Mędelska, J. (2000). Język polskiej prasy wileńskiej (1945-1979): Vol. 2. Lata 1945-1959. Wydawnictwo Uczelniane Wyższej Szkoły Pedagogicznej.

Mędelska, J. (2001). Język polskiej prasy wileńskiej (1945-1979): Vol. 3. Lata 1960-1979: Pt. 1. Fonetyka, słowotwórstwo, fleksja, składnia. Wydawnictwo Uczelniane Akademii Bydgoskiej im. Kazimierza Wielkiego.

Narodowy Korpus Języka Polskiego [NKJP]. (n.d.). http://nkjp.pl

Ohorilko, O. (2009). Osoblyvosti imennykovoï ta prykmetnykovoï slovozminy v tekstakh pol's'komovnoï presy Ukraïny. Komparatyvni doslidzhennia slov'ians'kykh mov ta literatur, $10,130-137$.

Ohorilko, O. (2014). Syntaksychni osoblyvosti tekstiv suchasnoï pol's'komovnoï presy v Ukraïni [Unpublished doctoral dissertation]. L'vivs'kyi natsional'nyı̆ universytet imeni Ivana Franka.

Słowo do czytelników. (2007, September). Gazeta Polska Bukowiny, 2007(1-2), 1. https:// bukpolonia.cv.ua/images/gazetapolskabukowiny/2007/2007_N1-2.pdf

Szymczuk, W. (2012). Prasa mniejszości polskiej na Ukrainie. Europejskie Centrum Edukacyjne.

Zabrocki, L. (1963). Wspólnoty komunikatywne w genezie i rozwoju języka niemieckiego: Pt. 1. Prehistoria języka niemieckiego. Ossolineum.

Zelins'ka, M. (2018). Komunikatyvna kompetentsiia molodykh nosïv pol's'koï movy zakhidnykh oblastě̆ Ukraïny. Posvit.

\section{„Gazeta Polska Bukowiny” jako źródło do badań współczesnej polszczyzny pisanej na Ukrainie}

\section{Streszczenie}

Celem publikacji jest przedstawienie „Gazety Polskiej Bukowiny”, ukazującej się od 2007 roku na Ukrainie, jako źródła do badań nad współczesną polszczyzną pisaną w tym kraju w warunkach jej kontaktu z innymi językami. Na tle pokazania stanu 
badań nad językiem prasy polskiej mniejszości narodowej na Ukrainie omawia się zalety i perspektywy studiów językoznawczych prowadzonych na materiale tekstów "Gazety Polskiej Bukowiny”, w tym także z uwzględnieniem - jako narzędzia badawczego - utworzonego na potrzeby naukowe elektronicznego korpusu tego periodyku. Podaje się charakterystykę gazety (czas wydawania, struktura, zakres tematyczny publikacji, ich autorzy, redakcja) i najogólniej określa się zasięg odstępstw od ogólnopolskiej normy językowej, które można analizować na podstawie tekstów publikacji pisanych przez osoby polskiego pochodzenia. Dokładniej zaś specyfikę językową ilustruje się na przykładzie deklinacyjnych form rzeczownika odbiegających od normatywnych odpowiedników ogólnopolskich. Przytacza się komentarze o możliwych wpływach zewnątrzinterferencyjnych w wyniku kontaktów polszczyzny z językiem ukraińskim i - bezpośrednio lub pośrednio - rosyjskim, który aktywnie funkcjonuje na Ukrainie obok języka państwowego.

Słowa kluczowe: polszczyzna pisana na Ukrainie; „Gazeta Polska Bukowiny”; źródło materiałowe; interferencja; norma językowa; deklinacja rzeczownika; korpus elektroniczny

\title{
The Magazine Gazeta Polska Bukowiny as a Source for the Study of Contemporary Written Polish in Ukraine
}

\begin{abstract}
This article presents the magazine Gazeta Polska Bukowiny [The Polish Gazette of Bukovina], which has been published in Ukraine since 2007, as a source for the study of contemporary written Polish under the conditions of its contact with other languages in Ukraine. The analysis is set against the background of research on the press of the Polish national minority in the country. The article offers a discussion of the advantages and prospects of the linguistic study of texts published in Gazeta Polska Bukowiny, including the use of the electronic corpus of this periodical as a research tool. The study outlines the characteristics of the magazine (time of publication, structure, topics of texts, their authors, editing) and, in the most general terms, the scope of deviations from the general Polish norm, which can be analysed on the basis of texts written by people of Polish descent. The linguistic specificity of these texts is more precisely illustrated on the example of case forms of nouns which deviate from their normative Polish equivalents. The author considers the potential impact of interference resulting from contact between Polish and Ukrainian and - directly or indirectly - Russian, which functions in Ukraine alongside the official language of the country.
\end{abstract}


Keywords: written Polish in Ukraine; Gazeta Polska Bukowiny; source material; interference; language norm; declension of a noun; electronic corpus

Prof. Dr Alla Kravchuk, Head of the Department of Polish Philology at the Ivan Franko National University of Lviv, Ukraine. PhD - 1999 (Academy of Sciences in Kyiv), associate professor - 2003, professor - 2015; author of seven and co-author of two textbooks and manuals for teaching Polish; author of over ninety scholarly articles; co-editor of six collective volumes; supervisor of eight completed $\mathrm{PhD}$ theses. She has conducted research on the semantics of Polish and Ukrainian phraseological units with an onomastic component, language errors in Polish of Ukrainians, polite forms in oral and written heritage Polish in Ukraine, and issues of ethnolinguistics and normativism.

Bibliography (selected): Антична й біблійна ономастична фразеологія польської та української мов: контрастивний аспект [Ancient and biblical phraseological units with an onomastic component in Polish and Ukrainian: Contrastive aspect], Slavia Orientalis 48 (2), Warszawa (Warsaw) 1999, 239-253; Problemy normy języka polskiego w kraju i za granicą (na Ukrainie) [Norms of the Polish language used in Poland and abroad (in Ukraine) as a research problem], Roczniki Humanistyczne 60 (6), Lublin 2012, 133-167; Rozwój polonistyki na Uniwersytecie Lwowskim [Development of the Polish Philology at the University of Lviv], Język Polski 93 (3), Kraków (Cracow) 2013, 150-161; Specification of selected honorifics in relation to the general Polish standard in the written Polish as a heritage language in Ukraine (using the material of the Polish-language Gazeta Polska Bukowiny periodical), Acta Universitatis Lodziensis: Kształcenie Polonistyczne Cudzoziemców 26, Łódź (Lodz) 2019, 311-327.

Correspondence: Alla Kravchuk, Department of Polish Philology, Ivan Franko National University of Lviv, Lviv, Ukraine, e-mail: alla.kravchuk@lnu.edu.ua Support of the work: The study was conducted at the author's own expense.

Competing interests: The author is a reviewer for this journal, but has not reviewed any texts in this volume.

Publication History: Received: 2020-10-22; Accepted: 2021-03-11; Published: 202112-21. 